\title{
On Cross - culture Management of Enterprises
}

\author{
Xiaorong $\mathrm{Li}^{1, \mathrm{a}}$ and Qing Zhang ${ }^{2, \mathrm{~b}^{*}}$ \\ ${ }^{1}$ Jiangxi Institute of Economic Administrators, Nanchang, Jiangxi Province, China \\ ${ }^{2}$ Lecturer of Art Institute of East China University of Technology, Nanchang, Jiangxi Province, China \\ a113225924@qq.com, ${ }^{b} 406589470 @ q q . c o m$ \\ * The Corresponding Author
}

Keywords: Cross-cultural management; Corporate culture; Strategy research

\begin{abstract}
At present, with the deepening economic globalization and cultural diversification, the world has been moving toward a direction that is more open, inclusive, balanced and win-win strategy. The "One Belt, One Road" strategy has provided significant opportunities and challenges for multinational corporations to "go global". However, in the course of their development, multinational corporations inevitably need to face the pains caused by differences in foreign cultures and conflicts. To solve problems of cross-cultural management and cultural integration is important for the enhancement of the soft power of corporate culture and the long-term development of enterprises. Based on the concept analysis, case analysis, opportunity challenge and strategy exploration of cross-cultural management of enterprises, this paper puts forward the coping strategies of multinational corporations management, which provides advice for multinational corporations carrying out effective and reasonable cross-culture management.
\end{abstract}

\section{Introduction}

General Secretary Xi Jinping pointed out in the 19th Chinese Communist Party National Congress that "implementing the new development concept and building a modern economic system" should focus on building the "One Belt and One Road" and foster a world-class enterprise with global competitiveness. As the pace of economic globalization accelerates, the construction of world-class enterprises will inevitably face the impact of culture conflicts. How to manage the enterprises under the system of foreign cultures has become a realistic problem for the development of many multinational corporations. Cross-cultural management is imperative.

\section{The Meaning of Cross-cultural Management}

Cross-cultural management originated from the economic and cultural exchanges between countries and countries in ancient societies. Until peace and development became the theme of the world, cross-cultural management was once again emerging as an upsurge of research with the rapid development of multinational corporations. One of the most representative is the cross-cultural management research of the United States and Japan. Cross-culture management refers to the process of economic management of multinational corporations carrying out continuous culture integration and encourage employees to form a cultural identity for management activities on the basis of existing corporate culture in the process of economic globalization, facing culture conflicts. The study of cross-culture management provides suggestions for the development of multinational corporations and promotes the further development of economic globalization.

\section{Problems and Influence of Cross-culture Management in Enterprises}

Problems of Cross-culture Management in Enterprises. From the perspective of a broad cultural perspective and in combination with the realities that some enterprises in the tide of economic globalization are facing, multinational corporations are faced with many conflicts at various levels, including cultural values, political systems and laws, which is mainly as follows:

Corporate Culture: Lack of core corporate values, cross-culture training and incentive mechanisms are not healthy. At present, some multinational corporations do not have the common 
values of enterprises, choose cultural evasion tactics and selectively ignore the differences among different cultures. The inadequate handling of cultural evasion tactics can easily lead to the inability to form new corporate values. Cross-culture training and incentive mechanisms are also crucial. For example, some Chinese multinational corporations have obviously single culture training programs. Employees in overseas branches take lectures to learn the cultural backgrounds of the foreign countries. Stiff learning modes and superficial learning contents result in counterproductive effects. It is easy to reduce employees' enthusiasm and produce conflicts between expatriate staff and local employees. Multinational corporations in China generally implement the "equal work but unequal payment" system on employee incentive measures, which has seriously affected the work enthusiasm and cultural identity of employees and is extremely unfavorable to the long-term development of the enterprise.

Political system: government instability and unreasonable government intervention. In terms of the political system, the instability of some foreign governments and common unreasonable interventions have led to the cultural conflicts of multinational corporations. Differences of the governments between the mother country of multinational corporations and the country where the investment is cover all aspects of political life. Commonly, restrictions are imposed on multinational corporations through the measures such as economic intervention, trade barriers, anti-dumping, regulatory and policy interventions. In 2017, China's Lenovo Group was investigated in the acquisition of IBM servers by U.S. government in the name of national security. CFIUS is concerned that Pentagon's network would be remotely accessed or destroyed by Chinese spies, which led to Lenovo's \$ 2.3 billion came to a standstill. 30 years ago, Lenovo's $\$ 1.75$ billion acquisition of IBM's loss-making ThinkPad business was not smooth. The U.S. government conducted a series of economic reviews to obstruct the normal conduction.

Legal System: Special Regulation Caused by Legal Risks. The cross-cultural challenges brought by the differences of legal system and system mainly focus on special supervision and judicial interpretation. For example, the "Aixon-Florio Amendment" adopted by the United States as early as the 1990s passed a law that regulates the way foreign companies purchase state-controlled enterprises in their countries. However, the law did not make a clear explanation of what the term "acts involving national security" means. So that the United States still uses this vague legal loophole to arbitrarily decide the operation and merger of multinational corporations. In addition, the unpredictable emergency laws in some countries have also challenged the development of multinational corporations. It is not uncommon for the government to achieve the so-called "safeguarding of national security" by interpreting the ambiguous clauses.

The Impact of Cross-culture Management of Enterprises. Undermine the internal stability of multinational corporations. Cultural conflicts that multinational companies face in their business operations in investment countries can lower their operational efficiency and greatly increase their overall operating costs. Managers and employees of multinational corporations have different cultural backgrounds, different interpretations and values of behaviors, which greatly reduces organizational coordination in the course of business operations, and even leads to the emergence of extreme antagonisms.

Reduce the market competitiveness of multinational corporations. All kinds of cultural conflicts do more harm than good to the competitiveness of enterprises, and the market share of enterprises gradually decreases. Cultural conflicts lead to the imbalance of internal coordination mechanism and the difficulty of multinational corporations in implementing large-scale management activities. Therefore, the efficiency of multinational corporations in carrying out their business activities is very low and they gradually lag behind in market competition.

Affect the overall strategic layout of multinational corporations. Conflicts with the locality's local culture are likely to evolve into a massive national boycott, and government departments may even take targeted measures. Finally, the operation and management of multinational corporations are in a dilemma, and the overall strategic layout has been greatly affected. Under the tide of economic globalization, multinational corporations need to constantly improve their core competitiveness all over the world. However, at present, the organizational management procedures 
of some multinational corporations are not chaotic, the values of their corporate culture are not formed, the boundaries of their job responsibilities are not clear, and some operations of multinational corporations are seriously affected, which may even lead to the global passive strategy of multinational corporations to become completely passive.

\section{Strategies and Pathways for Conducting Cross-culture Management of Enterprises}

Establish a Common System of Values. The cause of cross-culture management problems in enterprises is cross-culture conflicts, and the most important cause of cross-culture conflicts is the difference in value systems. Therefore, setting up a common value system within multinational corporations is an important prerequisite for effective cross-culture management of enterprises. However, the establishment of an enterprise's internal value system does not happen in one move, but a long process of formation. First of all, there must be ideological guidance on seeking common ground while putting aside differences, so as to face up to cultural differences and properly handle and embrace the existence of cultural differences such as respecting different ethnic and cultural beliefs, customs and so on. While enhancing cultural confidence, we must seek common ground while putting aside differences and enhance our understanding of the culture of other countries. The cultural integration within multinational corporations is not accomplished in a single step. Cultural conflicts will inevitably appear in various forms in the process of cultural integration. We should uphold the understanding of "going as far as the hometown" and insist on rational handling of conflicts to reduce the bad development.

Recognize the importance of cross-culture communication, resolve obstacles that arise in intercultural communication, and actively engage in cultural innovation in the process of communication. In the end, we must also form a unified concept of corporate culture that is endorsed by all employees to promote cultural integration and create a sense of cultural identity, which will allow employees to internalize the common cultural values within the organization in order to form a cohesive force role. Sinopec Corp gradually incorporated the corporate culture element into new Addax in its cross-cultural management after its acquisition of Addax Corporation in 2009: designing a new corporate logo and strengthening Sinopec Corp.'s influential factors in the region; making innovative adjustments, which gradually realizes the integration of cultural values, and ultimately promotes the healthy development of the enterprise.

Table 1 Detailed Process of Sinopec's Acquisition of Addax in 2009

\begin{tabular}{|c|c|}
\hline Time (2009) & Events \\
\hline Early March & $\begin{array}{l}\text { SIPC's financial advisors passes Addax's "Intention to Participate in the Addax } \\
\text { Acquisition Transaction" to Addax's Management }\end{array}$ \\
\hline April 23 & Addax executives and Sinopec executives met to discuss prices in London, England \\
\hline May & Continue to submit letters of intent and negotiate the price \\
\hline June 11 & $\begin{array}{l}\text { SIPC once again raised prices and stated that it would buy shares of Addax on a } \\
\text { contractual basis }\end{array}$ \\
\hline June 23 & $\begin{array}{l}\text { Submit the final quote. The Addax Board of Directors reviewed the offer of two } \\
\text { companies that competed for the acquisition and eventually decided to reach an } \\
\text { agreement on SIPC }\end{array}$ \\
\hline June 24 & $\begin{array}{l}\text { Addax signed a final agreement with SIPC before the opening at the price of } 52.8 \\
\text { Canadian dollars / share. }\end{array}$ \\
\hline August 18 & $\begin{array}{l}\text { China Petrochemical Corporation announced the successful acquisition of Addax } \\
\text { Oil Corporation of Switzerland, which is the largest overseas acquisition of Chinese } \\
\text { oil companies. }\end{array}$ \\
\hline
\end{tabular}

Form an Effective Cross-cultural Training Mechanism. Forming an effective intercultural training system is the most effective and fundamental way to promote the solution of cultural conflicts and better cross-culture management of enterprises. Some multinational corporations only focus on cross-culture training on the one hand, and the management and staff within the company have little knowledge of cross-culture management and have a great influence on the cross-culture 
management as a whole. Carrying out effective cross-culture training has a positive role in promoting high-quality management personnel training.

The content of training mainly includes language training, basic knowledge training and so on. Language training plays an important role in eliminating barriers to communication and further developing multinational enterprises. Training in basic knowledge carries out multi-dimensional training contents including basic knowledge, local literary knowledge and sensitivity knowledge, and training of employees' "cultural sensitivity" to avoid the emergence of conflicts, to provide the premise for cultural integration. Sinopec Corp.'s cross-culture management after its wholly-owned acquisition of Addax in 2009 is undoubtedly a success. After the company was stabilized, it implemented "Pearl Project" to improve the core cultural values from the following levels: "people-oriented, quality improvement and leadership building". Finally, on the basis of the original Addax culture, Sinopec Corp. creatively completed the process of cultural innovation, and finally promoted a series of scientific integration and sustained development of the parent company.

Table 2 Business after the Acquisition of Addax

\begin{tabular}{|c|c|c|c|c|}
\hline Item & $\begin{array}{c}\text { Business Income }(10,000 \\
\text { yuan) }\end{array}$ & $\begin{array}{c}\text { Business Profit } \\
(10,000 \text { yuan })\end{array}$ & $\begin{array}{c}\text { Gross profit margin } \\
(\%)\end{array}$ & $\begin{array}{c}\text { The } \\
\text { proportion of } \\
\text { the main } \\
\text { business } \\
\text { income }(\%)\end{array}$ \\
\hline $\begin{array}{c}\text { Exploration and } \\
\text { production }\end{array}$ & 12383500.00 & 4936500.00 & 39.86 & 9.21 \\
\hline Oil refining & 70357100.00 & 16286400.00 & 23.15 & 52.31 \\
\hline Chemicals & 21845700.00 & 3189200.00 & 14.60 & 16.24 \\
\hline $\begin{array}{c}\text { Marketing and } \\
\text { distribution }\end{array}$ & 78309100.00 & 6467800.00 & 8.26 & 58.22 \\
\hline Others & 52186900.00 & 304100.00 & 0.58 & 38.80 \\
\hline Offset Divisions & -100577100.00 & -260300.00 & 0.26 & -74.78 \\
\hline Sales & 134505200.00 & 30619600.00 & & 100.00 \\
\hline Total & & & & \\
\hline
\end{tabular}

\section{Conclusion}

Cross-cultural management of multinational corporations is a process of "conflict-innovation-integration" that ultimately leads to the formation of cultural identity among employees. To effectively carry out cross-cultural management, we must grasp the two aspects of cultural value system and cross-cultural training. Only in this way can multinational corporations gain a firm foothold in the wave of economic globalization and achieve a leap-forward stable development.

\section{References}

[1] Xiaomiao Lei. Facing Cultural Differences and Developing Cultural Identity - A Study of Cross-cultural Management in Multinational Corporations [J]. Business Research, 2017, (01): 13-18.

[2] Wei Xiong, Rui Qian. Cross-culture Management Needs "Unity of Nature and Humanity" [J]. Manager, 2017, (16): 88.

[3] Lei Yan, Jing Huang. Cross-country Management and Cross-culture Conflicts among Chinese Enterprises [J]. Journal of Henan Social Sciences, 2017,25 (03): 35-39.

[4] Detian Yang, Problems and Countermeasures of Cross-cultural Management of Chinese Multinationals - A Case Study of ZTE's Multinational Management [J] . China Management Informationization. 1992,19 (21): 91-93. 
[5] Dapeng Lv. China Sinopec intercultural management has won international acclaim [J]. China Petrochemical, 2016, (05): 81-83.

[6] International Management, Xinsheng Zhang, Yuan Wang, [Australia] Jeff Lassol, Michael M Burberry, et al. Renmin University of China Press, 2002.

[7] Cross-Cultural Management, Jun Hu [Editor]. Guangzhou: Jinan University Press, 1995.

[8] Cross-Cultural Management, [Switzerland] Susan C. Schneider, [France] Jane Louis Balsoks, translated by Shi Yongheng. Economic Management Publishing House, 2002.

[9] Cross-cultural Management, [British] Pat Jonat, Malcolm Warner; translated by Lu Changhuai, Sun Hongying, Yang Jie. Dongbei University of Finance and Economics Press, 1999.

[10] Research into Cross-cultural Management Issues in Corporate Transnational Business, Wu Diya, Master's Dissertation of Xiamen University.

[11] Cross-Cultural Management, Jianhua Liu, Knowledge Management Center of Cangli Company. 